\title{
Energijos veiksmingumo didinimo priemonės ir jų efektyvumas
}

\section{Dalia Štreimikienė,}

\section{Asta Mikalauskienè}

Lietuvos energetikos institutas, Kompleksiniu energetikos tyrimu laboratorija,

Breslaujos g. 3,

LT-44403, Kaunas

El.paštas:dalia@mail.lei.lt; astam@mail.lei.lt
Straipsnyje analizuojama energijos efektyvumo didinimo politika, pagrindinis dèmesys yra skiriamas energijos efektyvumo didinimo priemonems pastatuose, tiek namų ūkiuose, tiek paslaugų sektoriuje. Straipsnyje išanalizuoti ES energetikos politikos prioritetiniai dokumentai, skirti energijos efektyvumo didinimo politikos igyvendinimui, bei įvertinta Lietuvos pažanga igyvendinant energijos efektyvumo didinimo tikslus. Remiantis energijos taupymo ir šiltnamio efektą sukeliančių dujų mažinimo potencialo ir kaštų vertinimais, atliktais ES šalyse, pateikiamos rekomendacijos dèl Lietuvos energijos efektyvumo didinimo politikos igyvendinimo, orientuojant ją $\mathfrak{i}$ sektorius, pasižyminčius mažiausiais energijos taupymo ir šiltnamio dujų emisijų mažinimo kaštais bei dideliu energijos taupymo ir šiltnamio dujų emisijų mažinimo potencialu.

Raktažodžiai: energijos efektyvumo didinimas, energetikos politika, priemonès, pastatai

\section{IVADAS}

Energijos efektyvumo didinimas yra prioritetinè ES energetikos politikos sritis bei efektyviausias šiltnamio efektą sukeliančiu dujų (ŠESD) būdas. ES, igyvendindama energijos efektyvumo didinimo politiką, patvirtino daug svarbių politinių dokumentų bei direktyvų, nustatančių energijos efektyvumo didinimo tikslus bei priemones jiems igyvendinti. Pagal ES klimato ir energetikos paketą, kuris buvo patvirtintas $2007 \mathrm{~m}$., ES iki $2020 \mathrm{~m}$. nustatyti tokie tikslai:

- sumažinti išmetamụjų ŠESD kiekį ne mažiau kaip 20 \%, palyginti su 1990 m. kiekiais (30 \%, jei panašiai issipareigotų ir kitos išsivysčiusios šalys);

- padidinti energijos iš atsinaujinančių energijos šaltinių (vèjo, saulès, biomasès ir t. t.) naudojimą taip, kad ji sudarytų $20 \%$ viso pagaminamos energijos kiekio (šiuo metu ji sudaro apie 8,5\%);
- sumažinti energijos vartojimą $20 \%$, palyginti su numatomais $2020 \mathrm{~m}$. rodikliais, energiją èmus vartoti našiau.

2011 m. vasario mèn. Europos Taryba patvirtino ES tikslą - iki 2050 m. išmetamą ŠESD kiekị sumažinti 80-95 \%, palyginti su 1990 m., atsižvelgiant ị Tarpvalstybinès klimato kaitos grupès (TKKG) (angl. IPCC) nuomonę, kiek išsivysčiusios šalys (kaip grupè) turètų sumažinti išmetamụjų ŠESD kiekị, kad klimatas neatšiltų daugiau kaip $2{ }^{\circ} \mathrm{C}$.

2011 m. kovo 8 d. patvirtintas Konkurencingos mažo anglies dvideginio kiekio technologijų ekonomikos sukūrimo iki $2050 \mathrm{~m}$. planas, o $2011 \mathrm{~m}$. gruodžio $15 \mathrm{~d}$. EK pristatè Energetikos veiksmų planą iki $2050 \mathrm{~m}$.

Konkurencingos mažo anglies dvideginio kiekio technologijų ekonomikos sukūrimo iki $2050 \mathrm{~m}$. planas numato iki $2050 \mathrm{~m}$. sumažinti išmetamujjų ŠESD kieki 80-95\%, palyginti su 1990 m. (iki 2020 m. - $20 \%$, iki 
2030 m. - $40 \%$, iki 2040 m. - 60 \%), ir taip igyvendinti ilgalaiki Europos ịsipareigojimą prisidèti prie kovos su klimato kaita; beveik $100 \%$ elektros energijos būtų tiekiama naudojant mažo anglies dvideginio kiekio technologijas. Transporto sektoriuje išmetamą ŠESD kiekį numatoma sumažinti $60 \%$. Plane numatyta naujiems pastatams kuo skubiau pradèti taikyti beveik nulinès $\mathrm{CO}_{2}$ emisijos standartus ir užsibrèžti plataus užmojo tikslą - padidinti esamų pastatų energinį naudingumą, o pramonès - padidinti efektyvų energijos vartojimą ir pereiti prie mažiau energijai imlių gamybos būdų. Žemès ūkio ir miškininkystès sektoriuje plètoti efektyvų energijos vartojimą ir taikyti metodus, kurie padidintų dirbamos žemès pajègumą sugerti ir kaupti anglies dioksidą. Visiems minètiems tikslams pasiekti per artimiausius 40 metų kasmet reikès vidutiniškai $270 \mathrm{mlrd}$. EUR papildomų viešojo ir privačiojo sektorių investicijų. Tai sudaro 1,5 \% ES BVP arba $8 \%$ dabartinių investicijų.

Pastatų sektorius yra atsakingas už 38 \% ŠESD emisiju energetikos ir beveik už 20 \% visų ŠESD emisijų Lietuvoje [1]. Tarpvalstybinè klimato kaitos grupé nurodè, kad pastatų sektoriuje glūdi efektyviausias ŠESD emisijų mažinimo potencialas [2]. Taigi, svarbiausia klimato kaitos švelninimo priemonė yra energijos efektyvumo didinimas. O didžiausias energijos taupymo potencialas, realizuojamas mažiausiais kaštais, glūdi taupant energiją pastatuose. Darbo tikslas - išnagrinèti Lietuvos energijos efektyvumo didinimo politiką ir remiantis naujausiais tyrimais šioje srityje pateikti rekomendacijas dèl energijos efektyvumo didinimo politikos ir priemonių parinkimo Lietuvoje siekiant igyvendinti energijos efektyvumo didinimo tikslus.

Darbui keliami šie uždaviniai:

- išanalizuoti ES energetikos politikos ilgalaikius prioritetus;

- pateikti energijos taupymo ir šiltnamio dujų emisiju mažinimo priemonių kaštų ir potencialo vertinimą;

- ìvertinti Lietuvos pažangą igyvendinat ES energetikos politikos prioritetus energijos taupymo ir šiltnamio dujų emisijų mažinimo srityse;

- pateikti rekomendacijas dèl ES energetikos politikos prioritetinių tikslų energijos taupymo srityje igyvendinimo Lietuvoje.

ES energetikos politikos prioritetai ir igyvendinimo instrumentai

2007 m. kovo mèn. ES aukščiausiojo lygio susitikime susitarta dèl privalomo tikslo - iki $2020 \mathrm{~m}$. sumažinti bendrą išmetamų ES šiltnamio efektą sukeliančių dujų kiekį $20 \%$, palyginti su $1990 \mathrm{~m}$. lygiu. Jeigu kitos pramoninès šalys, tarp ju - JAV, imtųsi panašių priemonių, šis tikslas būtų padidintas iki $30 \%$. Be to, pasaulinè emisija iki $2050 \mathrm{~m}$. būtų sumažinta $50 \%$. Tai reiškia, kad išsivysčiusios šalys savo išmetamų teršalų kiekị sumažintų 60-80 \%. 2008 m. sausio 23 d. Europos Komisija pasiūlè priemonių, susijusių su klimato kaita ir atsinaujinančiais energijos šaltiniais, paketą, kuriame pasiūlè, kaip igyvendinti šiuos tikslus ir priimti pereinamojo laikotarpio (kuriant mažai anglies naudojantị ükį) priemones. 2008 m. komunikate „Du kartus po 20 iki 2020-ujjų"ES numato iki 2020 m. pasiekti šiu tikslų:

- ŠESD emisijų kieki iki 2020 m. sumažinti bent $20 \%$; šis tikslas būtu padidintas iki $30 \%$, jeigu bus pasiektas tarptautinis susitarimas, kuriuo kitos išsivysčiusios šalys prisiims panašius ịsipareigojimus;

- pasiekti, kad iki $2020 \mathrm{~m}$. atsinaujinančių energijos šaltinių energija sudarytų 20 \% ES sunaudojamos energijos;

- pasiekti, kad taupiau naudojant energiją, galutinès energijos sunaudojimą sumažinti $20 \%$.

I paketą įtrauktos gairès dèl patikslintos ES valstybès pagalbos aplinkos apsaugai ir teisèkūros pasiūlymai dèl:

- $\mathrm{CO}_{2}$ „naštos pasidalijimo“;

- taršos leidimų prekybos po $2012 \mathrm{~m}$;

- anglies dvideginio surinkimo ir saugojimo;

- atsinaujinančiu energijos šaltinių (įskaitant biokurą) panaudojimo.

Pagrindinis energetikos ir klimato pakete numatyto tikslo igyvendinimo mechanizmas yra ES taršos leidimu prekybos sistema, pradèta taikyti $2005 \mathrm{~m}$., siekiant padèti pasiekti Kioto protokole numatytą tikslą - iki $2012 \mathrm{~m}$. sumažinti šiltnamio efektą sukeliančiu duju išmetimą $8 \%$, nustatant didžiausias galimas išmetimo ribas energiją intensyviai naudojantiems sektoriams: plieno, cemento ir energijos gamintojams.

Siekiant igyvendinti Konkurencingos mažo anglies dvideginio kiekio technologijų ekonomikos sukūrimo iki 2050 m. planą, ES privalo:

- padidinti energijos vartojimo efektyvumą;

- užtikrinti energetikos sektoriaus dekarbonizaciją;

- realizuoti Europos elektros perdavimo, skirstymo, tiekimo tinklų potencialą siekiant sumažinti dekarbonizacijos kaštus ir riziką;

- užtikrinti perejjimo prie mažo anglies dvideginio ekonomikos finansavimą;

- skatinti atsinaujinančių energijos išteklių ir anglies dvideginio surinkimo ir saugojimo technologijų komercinę plètrą;

- igyvendinti priemones, kurios sukurtų vieningą mažo anglies dvideginio kiekio energijos rinką;

- užtikrinti reikiamą energetikos sektoriaus infrastruktūrą.

Svarbus vaidmuo, siekiant ilgalaikių tikslų, tenka šiuolaikinių technologijų diegimui:

- kasmet didinti energijos vartojimo efektyvumą $2 \%$;

- iškastini kurą pastatuose ir transporto sektoriuje planuojama pakeisti švaria elektra ir kitu mažai anglies dvideginio išmetančiu kuru; 
- plèsti anglies dvideginio surinkimo ir saugojimo technologijų panaudojimą.

Konkurencingos mažo anglies dvideginio kiekio technologijų ekonomikos sukūrimo iki $2050 \mathrm{~m}$. planas numato, jog:

- turi būti užtikrintas Direktyvos dèl pastatų energinio naudingumo igyvendinimas;

- energijos vartojimo efektyvumo didinimas yra tarp pagrindinių sričių, kuriai šalys narès turi skirti daugiau dèmesio;

- turi būti nustatyti ambicingesni tikslai energetinio efektyvumo priemoniu įdiegimui, kad dabartinis energetinio efektyvumo augimas būtų padidintas 2-3 kartus;

- be nacionalinių energijos vartojimo efektyvumo didinimo priemonių turi būti iggyvendinami ir atitinkami ES teisès aktai, kurie turi įtakos energijos vartojimo efektyvumui.

2011 m. gruodžio 15 d. EK pristate Energetikos veiksmų planą iki $2050 \mathrm{~m}$., kurio bendrasis tikslas - suformuoti viziją ir strategiją, kaip, atsižvelgiant $i$ tiekimo saugumo ir konkurencingumo tikslus, iki $2050 \mathrm{~m}$. sumažinti anglies dvideginio išmetimą ES energetikos sistemoje. Bendrajam tikslui pasiekti siūlomi konkretesni uždaviniai:

- investuotojams aiškiau nurodyti galimas būsimas ES politikos kryptis, nurodyti skirtingas anglies dvideginio išmetimo sumažinimo iki $2050 \mathrm{~m}$. priemones, taip pat tų priemonių poveiki ekonomikai, socialinị poveikị ir poveiki aplinkai;

- parodyti, kaip reikès siekti kompromiso tarp politikos tikslų ir skirtingų anglies dvideginio išmetimo mažinimo priemonių, taip pat nustatyti bendrus visų anglies dvideginio išmetimo mažinimo priemonių aspektus;

- nustatyti etapus po $2020 \mathrm{~m}$. (siekiant pritraukti suinteresuotas šalis) ir suteikti daugiau tikrumo dèl laikotarpio po $2020 \mathrm{~m}$.

Veiksmų planas iki $2050 \mathrm{~m}$. turètų būti grindžiamas dabartiniais tikslais: darnumu, tiekimo saugumu ir konkurencingumu.

Kadangi be nacionalinių energijos efektyvumo didinimo priemonių turi būti igyvendinami atitinkami ES teisès aktai, svarbu susisteminti pagrindines esamas ir pasiūlytas ES direktyvas, reguliuojančias energijos efektyvumo didinimo klausimus (1 lentelè).

Kadangi ES energetikos prioritetiniai tikslai, numatyti naujausiuose politikos dokumentuose, skatinamas šiuolaikinių technologijų diegimas, o iškastinị kurą pastatuose ir transporto sektoriuje planuojama pakeisti švaria elektra ir kitu mažai anglies dvideginio išmetančiu kuru, svarbu ivvertinti energijos efektyvumo didinimo bei ŠESD emisijų mažinimo potencialą bei kaštus atskiruose sektoriuose bei igyvendinant atskiras priemones. Tai leistų nustatyti tinkamiausias energijos efektyvumo didinimo priemones Lietuvoje.

\section{ENERGIJOS EFEKTYVUMO DIDINIMO PRIEMONIŲ BEI ŠILTNAMIO DUJŲ EMISIJŲ MAŽINIMO POTENCIALAS IR KAŠTAI}

Pagrindinès klimato kaitos švelninimo priemonès yra nukreiptos i energijos gamybą ir vartojimą, nes šiame sektoriuje ŠESD emisijos sudaro per 50 \% visų ŠESD emisiju išsivysčiusiose šalyse. Visos politikos priemonès, nukreiptos ŠESD emisijų mažinimui energetikos sektoriuje, siekia sukurti iniciatyvas taupyti energiją tiek gamyboje, tiek tarp vartotojų, pereiti nuo organinio kuro prie atsinaujinančiu energijos išteklių bei keisti energijos vartojimo struktūrą mažiau anglies turintị kurą (atominè energetika, gamtinès dujos). Atlikta nemažai studijų, skirtų klimato kaitos švelninimo priemonių efektyvumui vertinti [3-6], tačiau jų gauti rezultatai mažai skiriasi, nors taikomi skirtingi metodai ir prielaidos. Kita alternatyva yra anglies surinkimas ir saugojimas [7]. Šios skirtingos ŠESD mažinimo priemonès pasižymi skirtingais kaštais. Remiantis atliktais tyrimais $[8,9]$, galima pateikti ŠESD emisijų dèl kuro deginimo mažinimo kaštų 2006 ir 2016 m. (2 lentelè).

Kaip matyti iš 2 lentelëje pateiktų duomenų, energijos taupymas yra efektyviausias ŠESD emisijų mažinimo būdas, nes įdiegus energijos taupymo priemones elektros kaina išaugtų apie $3 \mathrm{JAV} \mathrm{ct} / \mathrm{kWh}$, kartu užtikrinant apie 1 sutaupytą JAV ct/kWh. Kitas pigiausias ŠESD emisijų mažinimo būdas yra atominès energijos panaudojimas. Vejo energijai vis labiau pingant, jos elektros energijos gamybos kaštai greitai gali susilyginti su atominių jegainių.

Be ŠESD emisijų mažinimo deginant kurą, egzistuoja ir ŠESD emisiju mažinimo galimybès kitose ŠESD srityse, pvz., pramoneje, žemės ūkyje, atlieku sektoriuje. Remiantis atliktais tyrimais [10], pateikiamos ŠESD emisijų mažinimo alternatyvos (pav.). Paveiksle pateikti ŠESD emisijų mažinimo kaštai EUR/tCO iki 2030 m. augimo tvarka. Vienas stulpelis atitinka $1 \mathrm{Gt} \mathrm{CO}_{2}$ eq.

Kaip matyti iš paveiksle pateiktų duomenų, kaštai (kai kurie iš jų yra net ne kaštai, o absoliuti nauda) siekia $40 \mathrm{EUR} / \mathrm{tCO}_{2}$. Su mažesniais nei $40 \mathrm{EUR} / \mathrm{tCO}_{2}$ kaštais galima iki 2030 m. sumažinti ŠESD emisijas 27 Gt. Paveiksle pateiktos efektyviausios ŠESD mažinimo alternatyvos, kurių kiekviena lemia ŠESD sumažinimą 1 Gt. Apie $7 \mathrm{Gt}$ ŠESD emisijų galima sumažinti su neigiamais arba nuliniais kaštais [10]. Kaip matyti iš paveiksle pateiktų ŠESD emisijų mažinimo alternatyvų, pigiausias ŠESD emisiju mažinimas yra galimas taupant energiją pastatuose, ypač gerinant patalpų apšiltinimą ir izoliaciją. Pastaroji priemonè leidžia sutaupyti net $140 \mathrm{EUR} / \mathrm{tCO}$ mažinant ŠESD emisijas 1 Gt. Efektyvesnių automobilių naudojimas taip pat leidžia sutaupyti $100 \mathrm{EUR} / \mathrm{tCO}_{2}$ sumažinant ŠESD emisijas $1 \mathrm{Gt}$. Efektyvesnès šildymo ir vèdinimo sistemos pastatuose leistų sutaupyti iki $80 \mathrm{EUR} / \mathrm{tCO}_{2}$ (sumažinant ŠESD $1 \mathrm{Gt})$. Efektyvesnès vandens šildymo sistemos igalintu 
1 lentelè. Pagrindinès ES direktyvos energijos efektyvumo didinimo srityje

\begin{tabular}{|c|c|}
\hline Priemonė & Priemonės aprašymas \\
\hline $\begin{array}{l}\text { ES direktyva 2004/8/EB dèl ko- } \\
\text { generacijos skatinimo, remiantis } \\
\text { naudingosios šilumos paklausa } \\
\text { vidaus energetikos rinkoje. }\end{array}$ & $\begin{array}{l}\text { Patvirtintas kogeneracijos plètros planas, kuriame efektyvi kogeneracija ir jos plètra } \\
\text { numatoma iki } 2012 \mathrm{~m} \text {. }\end{array}$ \\
\hline $\begin{array}{l}\text { ES direktyva 92/42/EB dèl naudin- } \\
\text { gumo koeficiento reikalavimų } \\
\text { naujiems karšto vandens } \\
\text { katilams, deginantiems } \\
\text { skystaji arba dujini kurą. }\end{array}$ & $\begin{array}{l}\text { Šioje direktyvoje nustatyti reikalavimai naudingojo veikimo koeficientui statant naujus } \\
\text { karšto vandens katilus, kurių vardinè atiduodamoji galia ne mažesnè kaip } 4 \text { kW ir ne } \\
\text { didesnè kaip } 400 \mathrm{~kW} \text {. Katilai turi atitikti šiuos naudingojo veikimo koeficientus: } 1 \text { ) esant } \\
\text { vardinei galiai, t. y. kai katilas naudojamas; esant vardinei galiai Pn, išreikštai kWh, ir esant } \\
\text { vidutinei katilo vandens temperatūrai } 70^{\circ} \mathrm{C} ; 2 \text { ) esant dalinei apkrovai, t. y. kai katilas nau- } \\
\text { dojamas esant } 30 \% \text { dalinei apkrovai ir vidutinei katilo vandens temperatūrai, kuri yra } \\
\text { skirtinga jivairiems katilų tipams. Standartiniams katilams reikalaujamas naudingojo } \\
\text { veikimo koeficientas esant vardinei atiduodamajai galiai yra } \geq 84+2 \text { logPn, esant dali- } \\
\text { nei apkrovai } \geq 84+2 \text { logPn. Žemos temperatūros katilams atitinkamai } \geq 84+2 \text { logPn ir } \\
\geq 84+2 \text { logPn, garus kondensuojantiems katilams } \geq 84+2 \text { logPn ir } \geq 84+2 \text { logPn. }\end{array}$ \\
\hline
\end{tabular}

ES direktyva 92/75/EEB dèl buitiniu prietaisų energijos ir kitų išteklių sunaudojimo parodymo ženklinant gamini bei pateikiant standartinę informaciją apie gamini.

ES direktyva 2005/32/EB dèl ekologinio projektavimo reikalavimų energiją vartojantiems gaminiams.
Igyvendinant direktyva jteisinti 9 techniniai reglamentai, skirti nurodyti buitiniu prietaisu energijos ir kitu svarbių ištekliu suvartojimą ženklinant gamini, ir teikti apie jị standartinę informaciją, tuo suteikiant vartotojams galimybę pasirinkti energijos požiūriu efektyviausius prietaisus.
Lietuvoje igyvendinama 2007 m. reglamentu (LR ūkio ministro ỉsakymas Nr. 4-438) „Ekologinio projektavimo reikalavimų energiją vartojantiems gaminiams nustatymo sistemos ir jos igyvendinimo priemoniu taikymo techninis reglamentas", kuris $2010 \mathrm{~m}$. gruodžio 17 d. Úkio ministro įsakymu Nr. 4-928 pakeistas nauja redakcija (Žin., 2007, Nr. 111-4555). Reglamentas nustato reikalavimus gaminiams, kuriems taikomos Europos Komisijos nustatytos igyvendinimo priemonès, kad šiuos gaminius galima būtų pateikti i rinką ir (arba) pradèti naudoti. Reglamentas ir pagal ji priimtos igyvendinimo priemonès suderintos su Europos Sajungos ir Lietuvos teisès aktais, reglamentuojančiais atliekų tvarkymą ir chemines medžiagas, ìskaitant teisès aktus dèl fluoro turinčių šiltnamio efektą sukeliančių dujų.

Direktyva 2010/31/EB dèl pastatu energinio naudingumo.

Pagrindinès Direktyvos 2010/31/ES dèl pastatu energinio naudingumo nuostatos, susijusios su energijos taupymu pastatuose: ne vèliau kaip iki $2013 \mathrm{~m}$. gruodžio 9 d. turi būti patvirtinta metodika energijos vartojimo efektyvumo reikalavimu griežtinimui; nuo $2018 \mathrm{~m}$. gruodžio $31 \mathrm{~d}$. nauji valstybinèms institucijoms priklausantys arba valdomi pastatai turi būti beveik nulinès energijos pastatai; iki 2020 m. gruodžio $31 \mathrm{~d}$. visi nauji pastatai turi būti beveik nulinès energijos pastatai. Valstybès narès turi parengti nacionalinius planus beveik nulinès energijos pastatų skaičiaus didinimui. Be to, numatomos papildomos paramos schemos.

\section{Direktyva 2010/30/EB dèl su} energija susijusių gaminių suvartojamos energijos ir kitu išteklių nurodymo ženklinant gamini ir apie ji pateikiant standartinę informaciją.

Pasiūlymas dèl energijos vartojimo efektyvumo direktyvos, kuria panaikinamos direktyvos 2004/8/EB ir 2006/32/EB.
Direktyvos paskirtis - suderinti nacionalines priemones, susijusias su informacija galutiniams naudotojams, ypač ženklinant ir pateikiant standartinę informaciją apie gaminį, taip pat susijusias su energijos naudojimu ir, prireikus, kitu svarbiu ištekliu suvartojimu gaminio naudojimo metu bei papildoma informacija apie su energija susijusius gaminius, taip suteikiant galutiniams naudotojams galimybę pasirinkti efektyvesnius gaminius.

Direktyva nustatoma bendra energijos vartojimo efektyvumo skatinimo Europos Sajungoje sistema siekiant užtikrinti, kad iki 2020 m. būtų pasiektas Europos Sajungos tikslinis rodiklis - sutaupyti $20 \%$ pirminès energijos ir sudarytos sąlygos vèliau energiją vartoti dar efektyviau. Direktyva numato, kad visi nauji šiluminès elektros energijos gamybos įrenginiai, kurių bendra šiluminè galia didesnè nei 20 MW, būtų aprūpinti įranga, leidžiančia išgauti naudotają šilumą pasitelkiant didelio naudingumo kogeneracijos jrenginį; irenginiai būtų pastatyti tokioje vietoje, kur naudotają šilumą galètu isisavinti šilumos poreikio punktai. sutaupyti 50/tCO ir sumažinti ŠESD emisijas dar $1 \mathrm{Gt}$. Taigi efektyviausi ŠESD emisijų mažinimo būdai yra pastatų bei transporto sektoriuose ir yra tiesiogiai susiję su namų ūkių energijos vartojimu, todèl ì tai pirmiausia ir reiktų atkreipti dèmesị $[11,12]$.

Energijos rezervavimo nuostolių mažinimas leistų sumažinti ŠESD emisijas $5 \mathrm{Gt} / \mathrm{metus,} \mathrm{sutaupyti} 10$ EUR/t
$\mathrm{CO}_{2}$; mažų $\mathrm{HE}$ ir atominès energijos panaudojimas - $1 \mathrm{Gt}$ ŠESD nuliniais ŠESD mažinimo kaštais; etanolio panaudojimas, miškų atsodinimas - 5 EUR/t kaštais; ŠESD emisijų mažinimas pramoniniuose procesuose kainuotų $10 \mathrm{EUR} / \mathrm{t}$ $\mathrm{CO}_{2}$. Žemès ūkyje ŠESD emisijų mažinimo kaštai siekia $25 \mathrm{EUR} / \mathrm{tCO}_{2}$, o atliekų srityje net $35 \mathrm{EUR} / \mathrm{tCO}$; ŽNPMA sektoriuje ŠESD emisijas sugerti kainuotų 6-20 EUR/tCO; 
2 lentelè. ŠESD mažinimo alternatyvos atskiruose sektoriuose

\begin{tabular}{|c|c|c|c|}
\hline $\begin{array}{l}\text { ŠD mažinimo } \\
\text { priemonés }\end{array}$ & $\begin{array}{l}\text { Kaštai, } \\
2006 \text { m. }\end{array}$ & $\begin{array}{l}\text { Kaštai, } \\
2016 \text { m. }\end{array}$ & Paaiškinimai \\
\hline $\begin{array}{l}30 \mathrm{JAV} \text { dol./t } \\
\text { anglies } \\
\text { mokestis }\end{array}$ & Apie $3 \mathrm{JAV}$ ct/kWh & Apie 3 JAV ct/kWh & $\begin{array}{l}\text { Anglies mokestis gali būti ịvedamas sumažinant kitus } \\
\text { mokesčius ir išlaikant nekintančias biudžeto pajamas, kad } \\
\text { nedidètų mokesčių našta. }\end{array}$ \\
\hline $\begin{array}{l}\text { Energijos } \\
\text { efektyvumo } \\
\text { didinimas }\end{array}$ & $\begin{array}{l}\text { Nuo } 1 \mathrm{JAV} \mathrm{ct} / \mathrm{kWh} \\
\text { naudos iki } \\
3 \mathrm{JAV} \text { ct/kWh kaštų }\end{array}$ & $\begin{array}{l}\text { Nuo } 1 \mathrm{JAV} \mathrm{ct} / \mathrm{kWh} \\
\text { naudos iki } \\
3 \mathrm{JAV} \mathrm{ct} / \mathrm{kWh} \\
\end{array}$ & $\begin{array}{l}\text { Energijos gamybos ir vartojimo efektyvumo didinimas yra } \\
\text { efektyviausia ŠESD emisijų mažinimo priemonè. Ypač didelis } \\
\text { potencialas glūdi taupant pastatų energiją. }\end{array}$ \\
\hline $\begin{array}{c}\text { Saulès } \\
\text { energija }\end{array}$ & $20 \mathrm{JAV} c t / k W h$ & 10-14 JAV ct/kWh & $\begin{array}{l}\text { Saulès kolektorių irengimas namuose ir versle gali akivaizdžiai } \\
\text { sumažinti ŠESD emisijas. Pagamintos energijos perteklius gali } \\
\text { būti perduotas į tinklą. } \\
\text { Saulès energijos kaštai per paskutinį dešimtmetị mažèjo } 5 \% \\
\text { per metus. Saulès energija vis dar yra brangiausia atsinauji- } \\
\text { nančiu energijos išteklių technologija, tačiau šių technologiju } \\
\text { integravimas pastatuose gali pagreitinti kaštų mažejimą. }\end{array}$ \\
\hline $\begin{array}{c}\text { Vejo } \\
\text { energija }\end{array}$ & 5-7 JAV ct/kWh & 3-6 JAV ct/kWh & $\begin{array}{l}\text { Vèjo energija jau yra pigesnè už gamtinių dujų deginimą tam } \\
\text { tikrose vietovèse. Vokietijoje vejjo energija pagamina } 10 \% \\
\text { visos šioje šalyje suvartojamos elektros. } \\
\text { Jos kaštai ir toliau mažejja, o turbinos darosi vis efektyvesnès. }\end{array}$ \\
\hline Biomasè & 7-9 JAV ct/kWh & $3-6 \mathrm{JAV}$ ct/kWh & $\begin{array}{l}\text { Biomasė gali būti deginama su gamtinèmis dujomis arba iš } \\
\text { jos galima pagaminti etanolị ir juo pakeisti trečdalị suvarto- } \\
\text { jamo benzino. }\end{array}$ \\
\hline $\begin{array}{l}\text { Hibridiniai ir } \\
\text { etanolio kurą } \\
\text { vartojantys } \\
\text { automobiliai }\end{array}$ & $\begin{array}{l}2000-5000 \text { JAV dol. } \\
\text { brangesni nei } \\
\text { paprasti automobiliai }\end{array}$ & $10 \mathrm{JAV}$ dol./kWh & $\begin{array}{l}\text { Hibridiniai ir etanolį vartojantys automobiliai gali sumažinti } \\
\text { ŠESD emisijas, tačiau šiuo metu jie yra pakankamai brangūs ir } \\
\text { vartotojams reikia sukurti papildomas paskatas jais naudotis, } \\
\text { o taip pat būtinas biokuro degalinių tinklas. }\end{array}$ \\
\hline $\begin{array}{l}\text { Atominè } \\
\text { energija }\end{array}$ & $3 \mathrm{JAV}$ ct/kWh & $3 \mathrm{JAV}$ ct/kWh & $\begin{array}{l}\text { Atominės elektrinės yra efektyvus elektros gamybos būdas } \\
\text { išvengiant ŠESD emisijų, tačiau saugumo reikalavimai bei } \\
\text { panaudoto kuro saugojimas kelia daug problemų. }\end{array}$ \\
\hline $\begin{array}{l}\text { Anglies } \\
\text { surinkimas ir } \\
\text { saugojimas }\end{array}$ & $3 \mathrm{JAV} \mathrm{ct} / \mathrm{kWh}$ & $3 \mathrm{JAV} \mathrm{ct} / \mathrm{kWh}$ & $\begin{array}{l}\text { Anglies dvideginio surinkimas ir saugojimas (ypač anglimi } \\
\text { kūrenamose jègainėse) šiuo metu vis labiau populiarėja. } \\
\text { Technologijos tampa vis pigesnės ir labiau prieinamos, } \\
\text { tačiau jos yra laikinos ir kyla ištekejjimo grèsmè. }\end{array}$ \\
\hline
\end{tabular}

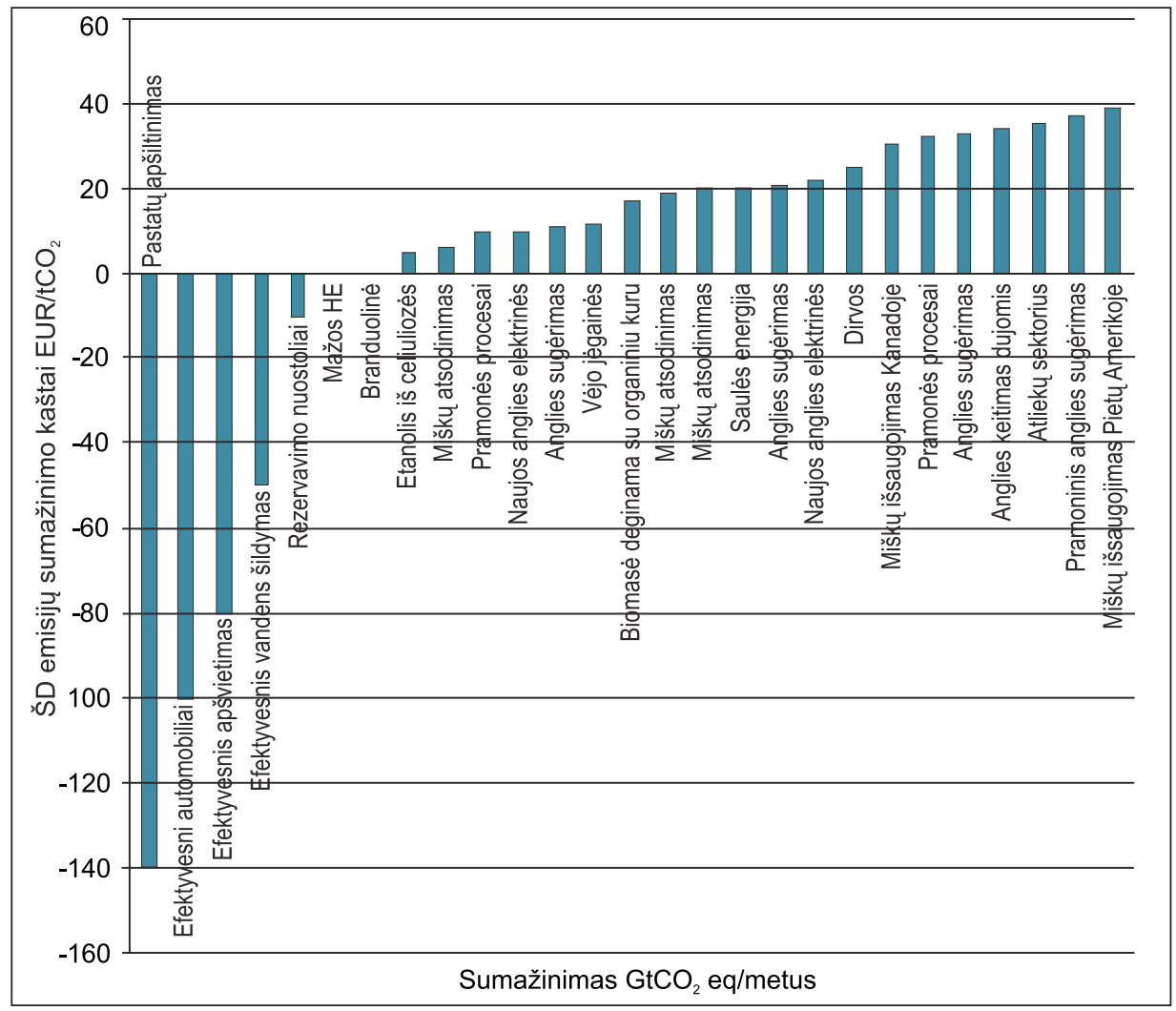

Pav. ŠESD emisijų mažinimo potencialas ir kaštai, ivertinti $\mathrm{EUR} / \mathrm{t} \mathrm{CO}_{2}$ iki $2030 \mathrm{~m}$. 
anglies surinkimas ir saugojimas kainuotų apie 12-21 EUR/ $\mathrm{tCO}_{2}$; vèjo energijos panaudojimas - $12 \mathrm{EUR} / \mathrm{tCO}_{2}$; saulès energijos - $20 \mathrm{EUR} / \mathrm{tCO}_{2}$; biomasès deginimas su organiniu kuru - $17 \mathrm{EUR} / \mathrm{tCO}_{2}$.

Taigi, ŠESD emisijų mažinimo priemonès pirmiausia turètų būti nukreiptos ị energijos vartojimo efektyvumo didinimą pastatuose. Kitos geriausios priemonès pagal ekonominị efektyvumą būtų atsinaujinančių energijos išteklių panaudojimas transporte ir elektros energijos gamyboje. Mažosios hidroelektrinès yra ekonomiškai efektyviausias ŠESD emisijų mažinimo būdas elektros energijos gamyboje. Vèjo jègainès yra pigiausias ŠESD emisijų mažinimo būdas elektros sektoriuje po atominès elektrinès. ŠESD emisijų mažinimas pramonès procesuose, žemès ūkyje ir atliekų srityje, kaip matyti iš paveiksle pateiktų duomenų, yra daug brangesnis.

Kadangi energijos taupymas pastatuose yra veiksmingiausias ir ekonomiškai efektyviausias būdas šiltnamio dujų emisijoms mažinti, jam Lietuvoje reikètų skirti daugiausiai dèmesio $[13,14]$. Toliau išnagrinèsime energijos veiksmingumo didinimo priemonių efektyvumą bei pateiksime rekomendacijas igyvendinant jas Lietuvoje.

Energijos taupymą skatinančias priemones galima suskirstyti i pagrindines grupes [15]:

- kontrolès ir reguliavimo priemonès (elektros prietaisų standartai, pastatų kodai, žalieji pirkimai; energijos efektyvumo didinimo reikalavimai ir kvotos);

- informacinès priemonès (privalomieji patikrinimai, energijos tiekimo įmonių poreikio valdymo programos, privalomas išsamesnès informacijos apie prekes ir paslaugas teikimas, privalomas sertifikavimas ir žymèjimas);

- ekonominiai ir rinkos instrumentai (lankstieji Kioto protokolo mechanizmai, baltieji sertifikatai, energijos veiksmingumo kontraktai ir kt.);

- fiskaliniai instrumentai (mokesčiai, mokesčių lengvatos, visuomeninių gèrybių mokesčiai, kapitalo subsidijos, grantai, palūkanų lengvatos);

- savanoriški issipareigojimai (savanoriškos sertifikavimo ir ženklinimo sistemos, savanoriški susitarimai su aplinkosauginèmis institucijomis, informavimo kompanijos, išsamesnès sąskaitos, visuomeninès lyderystès programos ir kt.).

Kontrolès ir reguliavimo priemonès yra labai efektyvios, tačiau nèra lanksčios ir ne visada leidžia realizuoti energijos taupymo potencialą [14]. Taip pat jos yra palyginti brangios. Informacinès priemonès apima išsamesnès informacijos apie siūlomas prekes ir paslaugas teikimą ir yra orientuotos ị tai, kad pirkèjui, kaip individui, priimančiam galutinius su vartojimu susijusius sprendimus (ką pirkti, kiek pirkti ir t. t.), būtų pateikta ne tik bendroji informacija apie produkto kiekị ir kokybę, kilmès šalị ir t. t., bet ir informacija apie naudotas žaliavas bei medžiagas ir potencialų produkto poveikị aplinkai per visą būvio ciklą. Čia svarbų vaidmenį turètų vaidinti specialusis ekologinis (žaliasis) ženklinimas, kuris rodo, kad šis gaminys arba yra pagamintas iš antrinių žaliavų, arba yra palankus aplinkai, t. y.jo gamybai ir eksploatacijai sunaudojama mažai energijos, jame nèra kenksmingų medžiagų ir t. t.

Ypač svarbu ugdyti aplinkai palankias vartotojų nuostatas. Čia itin svarbų vaidmenị turètų vaidinti švietimo ir ugdymo įstaigos. Kaip rodo pasauline patirtis, geriausi rezultatai pasiekiami, kai toks ugdymas prasideda dar vaiku darželiuose.

Vien priemonès, orientuotos í pirkejjo individualias nuostatas bei ịpročius, dažnai neduoda lauktų rezultatų, todèl pastaraisiais metais vis daugiau dèmesio skiriama palankios darniam vartojimui teisinès ir administracinès aplinkos kūrimui. Viena iš veiksmingiausių tokių priemonių yra Aplinkai palankių (žaliųjų) viešųjų pirkimų skatinimas. Žaliuoju pirkimu laikomas toks pirkimas, kai perkančioji organizacija ittraukia vieną ar kelis aplinkosaugos kriterijus ị viešojo pirkimo sąlygas, pasirinkdama prekes, paslaugas ir darbus ne tik pagal ju kainą ir kokybę, bet ir daromą mažesni poveikị aplinkai vienoje, keliose ar visose produkto būvio fazèse.

Ekonominiai bei rinkos instrumentai yra lanksčios energijos taupymą skatinančios priemonès ir leidžia siekti energijos vartojimo bei ŠESD emisiju mažinimo tikslų, užtikrinti ekonomini efektyvumą. Pvz., prekyba baltaisiais sertifikatais leidžia pirkti arba parduoti perteklinius sertifikatus atsižvelgiant $i$ i̇monès energijos taupymo galimybes ir kaštus. Fiskalinès priemonès yra lanksčios ir leidžia palyginti pigiai užtikrinti energijos taupymą taikant ekonominius stimulus. Mokesčių sistemos koregavimas (žalieji mokesčiai) yra kita svarbi administracinè energijos taupymą skatinanti priemonè. Būtinas vieno svarbiausių darnaus vystymosi principų - teršèjas moka - platesnis taikymas. Kol kas šis principas realiai taikomas tik gamintojams, jie moka mokesčius už aplinkos teršimą.

Savanoriški ịsipareigojimai yra trečios kartos aplinkosauginè priemonè, kurios pagrindinis principas yra aplinkosauginiu požiūriu atsakingų imonių konkurencingumo augimas dèl visuomenès palankaus požiūrio į tokias įmones.

Šalys taiko îvairius instrumentus ir priemones bei jų paketus energijos taupymui pastatuose užtikrinti. 3 lentelëje pateiktas kitose šalyse atliktų studijų, susijusių su energijos taupymo ir ŠESD emisijų mažinimo kaštų bei potencialo vertinimais, apibendrinimas $[4,8,15,16]$.

Kaip matyti iš lentelejje pateiktos informacijos, pigiausi ŠESD emisijų mažinimo instrumentai pastatų sektoriuje yra prekyba baltaisiais sertifikatais ir savanoriški susitarimai. Informacinès priemonès taip pat leidžia pigiai sumažinti ŠESD emisijas - 8 JAV dol./tCO ${ }_{2}$ Lankstieji Kioto protokolo mechanizmai leidžia užtikrinti ŠESD emisiju 
3 lentelè. Energijos taupymo ir ŠESD emisijų mažinimo potencialas ir kaštai pastatuose

\begin{tabular}{|c|c|c|c|}
\hline Politikos priemonè & Šalis/regionas & $\begin{array}{c}\text { Energijos arba emisijų mažinimo } \\
\text { potencialas }\end{array}$ & ŠESD emisijų mažinimo kaštai \\
\hline Prietaisų standartai & Europos Sajunga (ES) & & ES: - 194 JAV dol./tCO 2020 m. \\
\hline Statybos normos & $\begin{array}{l}\text { Europos Sajunga (ES), } \\
\text { Jungtinè Karalystè (JK), } \\
\text { Nyderlandai (NL) }\end{array}$ & $\begin{array}{c}\text { ES: } 35-45 \mathrm{MtCO}_{2^{\prime}} \\
\text { iki } 60 \% \text { naujiems pastatams } \\
\text { JK: } 2,88 \mathrm{MtCO}_{2} \text {, iki } 2010 \mathrm{~m} .\end{array}$ & $\begin{array}{c}\mathrm{NL} \text { : nuo - } 189 \mathrm{JAV} \text { dol./.tCO } \\
\text { iki - } 5 \mathrm{JAV} \text { dol./tCO } \mathrm{tCO}_{2} \text { galutiniams } \\
\text { vartotojams, 46-109 JAV dol./tCO } \\
\text { visuomeniniams vartotojams. }\end{array}$ \\
\hline Viešieji pirkimai & Europos Sajunga (ES) & ES: $20-44 \mathrm{MtCO}_{2}$ potencialas & $\mathrm{ES}:<21 \mathrm{JAV}$ dol./tCO \\
\hline $\begin{array}{c}\text { Energijos efektyvumo } \\
\text { [sipareigojimai ir kvotos }\end{array}$ & Jungtinè Karalystė (JK) & $\mathrm{JK}: 2,16 \mathrm{MtCO}_{2} / \mathrm{m}$ & JK: - $139 \mathrm{JAV}$ dol./tCO \\
\hline $\begin{array}{l}\text { Privalomos ženklinimo ir } \\
\text { sertifikavimo programos }\end{array}$ & Australija (AU) & $\begin{array}{c}\text { AU: } 5 \mathrm{MtCO}_{2} \text { sutaupymas } \\
1992-2000 \mathrm{~m} . \\
81 \mathrm{MtCO}_{2} 2000-2015 \mathrm{~m} . \\
\end{array}$ & $\mathrm{AU}:-30 \mathrm{JAV}$ dol./ $/ \mathrm{CO}_{2}$ \\
\hline $\begin{array}{l}\text { Poreikių valdymo programos } \\
\text { energijos tiekimo įmonėse }\end{array}$ & $\begin{array}{c}\text { Danija (DK), Europos } \\
\text { Sajunga (ES) } \\
\end{array}$ & DK: $0,8 \mathrm{MtCO}_{2}$ & $\begin{array}{c}\text { DK: - 209,3 JAV dol./t } \mathrm{tCO}_{2} \\
\text { ES: - } 255 \mathrm{JAV} \text { dol./ } / \mathrm{tCO}_{2} \\
\end{array}$ \\
\hline $\begin{array}{l}\text { Energijos paslaugų tiekimo } \\
\text { [sipareigojimai (ESCO) }\end{array}$ & Europos Sajunga (ES) & ES: 40-55 MtCO ${ }_{2}$ iki 2010 m. & ES: $<22$ JAV dol./t $\mathrm{tCO}_{2}$ \\
\hline $\begin{array}{c}\text { Prekyba baltaisiais } \\
\text { sertifikatais }\end{array}$ & Italija (I), Prancūzija (FR) & $\begin{array}{c}\text { I: } 1,3 \mathrm{MtCO}_{2} 2006 \mathrm{~m} . \\
3,64 \mathrm{MtCO}_{2} \text { eq iki } 2009 \mathrm{~m} .\end{array}$ & FR: 0,013 JAV dol./tCO ${ }_{2}$ \\
\hline $\begin{array}{c}\text { Kioto protokolo lankstieji } \\
\text { mechanizmai }\end{array}$ & Estija (EE), Latvija (LV) & $\begin{array}{c}\text { EE: } 3,8-4,6 \mathrm{KtCO}_{2} \text { (3 projektai) } \\
\text { LV: } 830-1430 \mathrm{tCO}_{2}\end{array}$ & $\begin{array}{l}\text { EE: 41-57 JAV dol./tCO } \\
\text { LV: - } 10 \text { JAV dol./tCO }{ }_{2}\end{array}$ \\
\hline Mokesčiai & $\begin{array}{c}\text { Europos Sajunga (ES), } \\
\text { Nyderlandai (NL) }\end{array}$ & $\mathrm{NL}: 0,5-0,7 \mathrm{MtCO}_{2} 2000 \mathrm{~m}$ & - \\
\hline Atleidimas nuo mokesčių & Prancūzija (FR) & FR: $1 \mathrm{MtCO}_{2} 2002 \mathrm{~m}$. & - \\
\hline Viešujų paslaugų mokesčiai & Nyderlandai (NL) & $\mathrm{NL}: 7,4 \mathrm{TWh} 1996=2,5 \mathrm{MtCO}_{2}$ & - \\
\hline $\begin{array}{c}\text { Subsidijos, dotacijos, } \\
\text { subsidijuojamos paskolos }\end{array}$ & Jungtinè Karalystè (JK) & $\begin{array}{l}\mathrm{JK}: 6,48 \mathrm{MtCO}_{2} / \mathrm{m} ., \\
100,8 \mathrm{MtCO}_{2} \text { iš viso }\end{array}$ & JK: 29 JAV dol./tCO \\
\hline $\begin{array}{c}\text { Savanoriški ir sutartiniai } \\
\text { susitarimai }\end{array}$ & $\begin{array}{c}\text { Europos Sajunga (ES), } \\
\text { Švedija (SE) }\end{array}$ & $\mathrm{ES}: 50 \mathrm{KtCO}_{2^{\prime}}, 100 \mathrm{GWh} / \mathrm{m}$. & SE: 0,0166 JAV dol./kWh \\
\hline $\begin{array}{c}\text { Viešosios lyderystès } \\
\text { programos }\end{array}$ & $\begin{array}{c}\text { Vokietija (DE), Europos } \\
\text { Sajunga (ES) } \\
\end{array}$ & $\begin{array}{l}\text { DE: } 25 \% \text { viešajam sektoriuje } \\
\mathrm{CO}_{2} \text { sumažinimas per } 15 \text { metų }\end{array}$ & $\begin{array}{c}\text { ES: } 13,5 \text { mlrd. JAV dol. } \\
\text { sutaupymas iki } 2020 \text { m. }\end{array}$ \\
\hline $\begin{array}{c}\text { Informuotumo didinimas, } \\
\text { švietimas }\end{array}$ & Jungtinè Karalystè (JK) & JK: $10,4 \mathrm{KtCO}_{2}$ kasmet & JK: $8 \mathrm{JAV}$ dol./$/ \mathrm{tCO}_{2}$ \\
\hline Išsamių sąskaitų programos & Jungtinè Karalystè (JK) & JK: $3 \%$ & - \\
\hline
\end{tabular}

mažèjimą pastatuose: Estijoje 41-57 JAV dol./tCO bei Latvijoje - $10 \mathrm{JAV}$ dol./ $\mathrm{tCO}_{2}$.

Brangiausios energijos taupymo ir ŠESD emisijų mažinimo priemonès pastatuose yra prietaisų standartai $194 \mathrm{JAV}$ dol./tCO 2 bei statybos normos - $189 \mathrm{JAV}$ dol./ $\mathrm{tCO}_{2}$ (Nyderlandai). Taip pat privalomos ženklinimo ir sertifikavimo sistemos - 209,3 JAV dol./tCO (Danija) bei $255 \mathrm{JAV}$ dol./tCO $(\mathrm{ES})$. Poreikių valdymo programos energijos tiekimo įmonèse taip pat gali būti priskiriamos prie brangiausių ŠESD emisijų mažinimo instrumentų - ŠESD emisijų mažinimo kaštai Danijoje siekia 209,3 JAV dol./tCO, o ES vidurkis - $255 \mathrm{JAV}$ dol./tCO 2 Taigi pigiausios energijos efektyvumo didinimo priemonès pastatuose yra ekonominès arba rinkos priemonès bei savanoriški ịsipareigojimai, o brangiausios - kontrolès ir reguliavimo priemonès.

Didžiausias ŠESD emisijų mažinimo potencialą gali užtikrinti viešųjų pirkimų ir statybų normų priemonès. Taip pat didelis ŠESD emisijų mažinimo potencialas glūdi ir subsidijose bei dotacijose. Iprasta, kad pigios priemonès, tokios kaip savanoriški susitarimai arba švietejjiškos priemonès, pasižymi mažu energijos taupymo ir ŠESD emisijų mažinimo potencialu, išskyrus viešuosius prikimus, kurie gali garantuoti 20-44 $\mathrm{MtCO}_{2} /$ metus ES (potencialas su mažesniais nei $21 \mathrm{JAV}$ dol./tCO $\mathrm{CO}_{2}$ SESD mažinimo kaštais).

Norint įvertinti Lietuvoje taikomų energijos efektyvumo priemonių rezultatyvumą bei pasiūlyti rekomendacijas dèl energijos efektyvumo didinimo politikos tobulinimo Lietuvoje, kitame skyriuje nagrinëjame Lietuvos energijos efektyvumo didinimo politiką ir jos rezultatus. Kadangi pastatų sektorius yra prioritetinè energijos taupymo sritis ES, leidžianti užtikrinti energijos taupymą ir ŠESD emisijų mažinimą mažiausias kaštais, šiai sričiai straipsnyje yra skirtas didžiausias dèmesys.

\section{ENERGIJOS EFEKTYVUMO DIDINIMO TIKSLŲ IGYVENDINIMAS LIETUVOJE}

Vienas iš pagrindinių Lietuvos energetikos strateginių tikslų yra efektyvus energijos vartojimas. Energijos vartojimo efektyvumo didinimas yra svarbus sprendžiant energetinio 
saugumo didinimo, energijos tiekimo diversifikavimo bei priklausomybės nuo iškastinio kuro importo mažinimo problemas. Siekiant sumažinti šiltnamio efektą sukeliančių dujų emisijas ir sušvelninti klimato kaitą, energijos vartojimo efektyvumas vaidina svarbų vaidmenị.

Energijos naudojimo efektyvumo didinimo srityje Europos Parlamento ir Europos Tarybos direktyvoje 2006/32/ EB valstybėms narèms nustatytas tikslas - sutaupyti $9 \%$ galutinès energijos suvartojimo vidurkio 2001-2005 m. Galutinis tikslas atitinka 3797 GWh. Pagrindinis Antrojo energijos efektyvumo veiksmų plano tikslas - aprašyti nacionalinio tarpinio energijos taupymo rodiklio pasiekimo rezultatus Lietuvoje [17]. Remiantis šiuo planu, bus įvertintas Lietuvos energijos efektyvumo didinimo politikos veiksmingumas ir pateiktos rekomendacijos jos tobulinimui.

Pagrindiniai dokumentai, turintys ịtakos galutinés energijos taupymui Lietuvoje, yra Nacionalinè energetinès nepriklausomybės strategija (energijos vartojimo efektyvumo didinimas yra vienas iš Lietuvos ilgalaikių strateginių tikslų), Nacionaliné energijos vartojimo efektyvumo didinimo programa (darnaus vystymosi tikslais suderintos energetikos politikos vykdymas, ịtraukiant energetikos efektyvumą ¡ tarp atskirų sričių), Lietuvos būsto strategija bei Ilgalaike (iki 2025 m.) Lietuvos transporto sistemos plètros strategija. 4 lentelèje pateikiami pagrindiniuose dokumentuose, turinčiuose ịtakos galutinès energijos taupymui Lietuvoje, numatyti energijos vartojimo efektyvumo didinimo uždaviniai.

Antrajame energijos efektyvumo veiksmų plane $2010 \mathrm{~m}$. sutaupytas ir $2016 \mathrm{~m}$. planuojamas sutaupyti galutinès energijos kiekis nustatytas „iš apačios ị viršų metodu ịvertinant kiekvienos individualios priemonès sutaupytą energijos kieki. 5 lenteleje pateikti apibendrinti sutaupytos energijos kiekiai sektoriuose.

Tarpinis (2008-2010 m.) energijos taupymo rodiklis trijų metų laikotarpiui yra 1,5\% galutinès energijos suvar-

\section{4 lentelè. Pagrindiniai energijos efektyvumo didinimo uždaviniai Lietuvos strateginiuose dokumentuose}

\begin{tabular}{|c|c|}
\hline Dokumentas & Uždaviniai \\
\hline $\begin{array}{l}\text { Nacionalinė energetinės nepriklausomybės strategija, patvirtinta } \\
2012 \text { m. birželio } 26 \mathrm{~d} \text {. Nr. XI-2133 LRS nutarimu dėl } \\
\text { Nacionalinės energetikos strategijos patvirtinimo. }\end{array}$ & $\begin{array}{l}\text { Strategijoje numatyta iki } 2020 \text { m. kasmet po 1,5 \% didinti } \\
\text { energijos vartojimo efektyvumą ir taip stiprinti energetinę } \\
\text { nepriklausomybę, konkurencingumą ir darnią plètrą. } \\
\text { Numatytos iniciatyvos turès teigiamą poveiki aplinkai - } \\
\text { jų igyvendinimas sudarys sąlygas Lietuvai iki } 2020 \text { m. } \\
\text { i atmosferą papildomai neišmesti } 11 \text { mln. tonų } \\
\text { šiltnamio efektą sukeliančių dujų ( } \mathrm{CO}_{2} \text { ekvivalentu). } \\
\text { Tai sudarytų } 46 \% 2008 \text { m. išmetamų faktinių šiltnamio } \\
\text { efektą sukeliančių dujų. }\end{array}$ \\
\hline $\begin{array}{l}\text { Nacionalinè energijos vartojimo efektyvumo didinimo programa. } \\
2006-2010 \text { m. programa, patvirtinta Lietuvos Respublikos } \\
\text { Vyriausybès } 2006 \text { m. gegužės } 11 \text { d. nutarimu Nr. } 443 \\
\text { (Žin., 2006, Nr. 54-1956). } \\
2010 \text { m. parengtas Nacionalinės energijos vartojimo } \\
\text { efektyvumo didinimo 2011-2015 m. programos ir } \\
\text { jos įgyvendinimo priemonių projektas. }\end{array}$ & $\begin{array}{l}\text { Programos uždaviniai - vykdyti su darnaus vystymosi tikslais } \\
\text { suderintą energetikos politiką, įtraukti energetikos efektyvumą } \\
\text { i šalies bendrają politiką derinant sektorių veiksmus, } \\
\text { sukuriant ir taikant atitinkamą reguliavimą bei vykdyti } \\
\text { taikomuosius mokslo tiriamuosius darbus, informavimo } \\
\text { ir šviečiamają veiklą efektyvaus energijos vartojimo } \\
\text { klausimais. }\end{array}$ \\
\hline $\begin{array}{l}\text { Lietuvos būsto strategija. Patvirtinta LR Vyriausybės } 2004 \text { m. } \\
\text { sausio } 21 \text { d. nutarimu Nr. } 60 \text { (Žin., 2004, Nr. 13-387). }\end{array}$ & $\begin{array}{l}\text { Strategijoje numatyta siekti, kad } 2020 \text { m. šiluminès energijos ir } \\
\text { kuro santykinės sąnaudos, skaičiuojamos būsto naudingo ploto } \\
\text { vienetui, sumažètų ne mažiau kaip } 30 \% \text {. }\end{array}$ \\
\hline $\begin{array}{l}\text { Ilgalaikè (iki } 2025 \text { m.) Lietuvos transporto sistemos plètros strategija. } \\
\text { Patvirtinta LR Vyriausybės } 2005 \text { m. birželio } 23 \text { d. } \\
\text { nutarimu Nr. } 692 \text { (Žin., 2005, Nr. 79-2860). }\end{array}$ & $\begin{array}{l}\text { Numatoma, kad kelių, geležinkelių, uostụ ir oro uostų } \\
\text { infrastruktūra turi būti modernizuojama ir plètojama koor- } \\
\text { dinuotai siekiant, kad intermodaliniai operatoriai galètų } \\
\text { naudoti efektyvias transportavimo technologijas bei proce- } \\
\text { sus ir kad būtų pasiekta jevairių transporto rūšių subalansuota } \\
\text { plètra, savo techniniais parametrais, sauga ir teikiamų } \\
\text { paslaugu kokybe prilygstanti ES šaliu (nariu senbuviu) lygiui. }\end{array}$ \\
\hline
\end{tabular}

5 lentelè. Sutaupyti energijos kiekiai sektoriuose $2010 \mathrm{~m}$. ir planas $2016 \mathrm{~m}$.

\begin{tabular}{|c|c|c|}
\hline Sektorius & 2010 m. sutaupyta GWh & 2016 m. planuojama GWh \\
\hline Namų ūkiai & 80 & 558 \\
\hline Paslaugų sektorius & 110 & 387 \\
\hline Pramonè & $\mathrm{n} / \mathrm{d}$ & 565 \\
\hline Energetikos sektorius & $\mathrm{n} / \mathrm{d}$ & 740 \\
\hline Transporto sektorius & $\mathrm{n} / \mathrm{d}$ & 472 \\
\hline Horizontaliosios priemonès & 590 & 1240 \\
\hline Iš viso: & 780 & 3962 \\
\hline
\end{tabular}


tojimo vidurkio 2001-2005 m. Skaitine išraiška tarpinis rodiklis atitinka $628 \mathrm{GWh}$, o galutinis tikslas atitinka 3797 GWh. 2008-2010 m. nustatytas ir Antrajame energijos efektyvumo veiksmų plane pateiktas sutaupytas galutinès energijos kiekis sudaro $780 \mathrm{GWh}$, t. y. 1,8 \% minètos 2006/32/EB direktyvos nustatyto galutinès energijos suvartojimo vidurkio $2001-2005 \mathrm{~m}$.

Kaip matyti iš 5 lentelëje pateiktos informacijos, tik namų ükiuose ir paslaugų sektoriuje bei dèl horizontaliųjų priemoniu igyvendinimo yra ịvertintas sutaupytos energijos kiekis. Kadangi energijos taupymas namų ūkių bei paslaugų sektoriuose yra visų pirma susijęs su energijos taupymu pastatuose, šiu sričių energijos efektyvumo didinimo priemones būtina išsamiau išnagrinèti.

Lietuvoje pastatus renovuoti bandoma jau gana seniai. Pasaulio Bankas Lietuvoje 1996-2002 m. vykdytą eksperimentini pastatų energinio efektyvumo projektą pavadino kaip labiausiai pavykusi pavyzdini renovacijos projektą. 2006 m. parengtame ir patvirtintame Pirmajame energijos efektyvumo veiksmų plane nustatyta, jog didžiausios energijos taupymo galimybès (ekonominis potencialas apie $30 \%$ ) yra pastatų sektoriuje. Šis potencialas gali būti panaudojamas renovuojant esamus pastatus ir modernizuojant senų pastatų energetines sistemas, taip pat naujų pastatų statybai naudojant energiją taupančias medžiagas bei naujausias energijos tiekimo bei apskaitos technologijas. Šiame sektoriuje naudojamos priemonès yra ypač svarbios, nes jų igyvendinimas leidžia išspręsti ne tik ekonomines, bet ir socialines problemas, kurios tiesiogiai susiję su gyventojų išlaidomis energijai bei su gyvenimo kokybe. Nuo 2005 iki $2011 \mathrm{~m}$. buvo renovuoti 357 daugiabučiai namai. Vidutiniškai $1 \mathrm{~m}^{2}$ sutaupyta $61 \mathrm{kWh} /$ metus. Planuojama, kad iki 2015 m. bus renovuota 200 daugiabučių namų.

6 lentelëje pateikiami namų ūkių sektoriuose iggvendinamų ir planuojamų igyvendinti energijos vartojimo ir efektyvumo didinimo priemonių aprašymai ir sutaupytos energijos skaitiné išraiška.

Galutinès energijos suvartojimas paslaugų sektoriuje iki 2000 m. mažéjo, tačiau nuo 2000 iki 2007 m. èmé augti (vidutiniškai kasmet 5,2 \%). Nuo 1996 iki 2010 m. elektros energijos sunaudojimas paslaugų sektoriuje padidejo $74 \%$, t. y. išaugusio elektros ir šilumos energijos naudojimo rezultatas, todèl energijos vartojimo efektyvumo didinimas šioje srityje yra ypač aktualus. 7 lentelëje pateikiami paslaugų sektoriuje igyvendinamų ir planuojamų igyvendinti energijos vartojimo efektyvumo didinimo priemonių aprašymas.

6 lentelè. Igyvendinamos ir planuojamos igyvendinti energijos vartojimo ir efektyvumo didinimo priemonès namu ūkiuose

\begin{tabular}{|c|c|c|c|}
\hline Priemonè & $\begin{array}{l}\text { Priemonès aprašymas } \\
\text { (tikslas) }\end{array}$ & $\begin{array}{l}2010 \mathrm{~m} . \\
\text { sutaupyta } \\
\text { GWh }\end{array}$ & $\begin{array}{c}2016 \mathrm{~m} . \\
\text { planuojama } \\
\text { sutaupyti GWh }\end{array}$ \\
\hline $\begin{array}{l}\text { Energijos taupymo demonstracinis projektas } \\
\text { (ankstyvieji veiksmai) }\end{array}$ & $\begin{array}{l}\text { Skatinti daugiabučių namų butų ir kitų } \\
\text { patalpų savininkus pasinaudoti parama } \\
\text { ir kompleksiškai modernizuoti } \\
\text { daugiabučius namus. }\end{array}$ & 20 & 20 \\
\hline $\begin{array}{l}\text { Daugiabučių namų atnaujinimo (modernizavimo) } \\
\text { programa (Žin., 2004, Nr. 143-5232; 2008, } \\
\text { Nr. 36-1282; 2009, Nr. 112-4776; 2010, } \\
\text { Nr. 72-3651) }\end{array}$ & $\begin{array}{l}\text { Skatinti daugiabučių namų butu ir kitu } \\
\text { patalpų savininkus pasinaudoti parama ir } \\
\text { kompleksiškai modernizuoti daugiabučius } \\
\text { namus bei gyvenamuosius rajonus } \\
\text { siekiant geresnės gyvenimo kokybės, } \\
\text { racionalaus energijos ištekliu naudojimo } \\
\text { ir biudžeto išlaidų mažinimo šildymo } \\
\text { išlaidoms kompensuoti. }\end{array}$ & 60 & 250 \\
\hline $\begin{array}{l}\text { Numatoma nauja priemonè - Visagino daugiabučių } \\
\text { namų atnaujinimo programa }\end{array}$ & $\begin{array}{l}\text { Atnaujinti daugiabučius namus, } \\
\text { pirmiausia didinant ju energijos } \\
\text { vartojimo efektyvumą lemiančias } \\
\text { savybes. }\end{array}$ & $n / d$ & 60 \\
\hline $\begin{array}{l}\text { 2007-2013 m. Sanglaudos skatinimo veiksmu programos } \\
1 \text { prioriteto „Vietinè ir urbanistinè plètra, kultūros } \\
\text { paveldo ir gamtos išsaugojimas bei pritaikymas } \\
\text { turizmo plètrai“ igyvendinimo priemonès } \\
\text { VP3-1.1-VRM-03-R „Daugiabučiu namu atnauji- } \\
\text { nimas pirmiausia didinant jų energijos vartojimo } \\
\text { efektyvumą" projektu finansavimo sąlygu apra- } \\
\text { šas (Žin., 2009, Nr. 62-2507; 2010, Nr. 128-6553) }\end{array}$ & $\begin{array}{l}\text { Atnaujinti daugiabučius namus, } \\
\text { pirmiausia didinant ju energijos } \\
\text { vartojimo efektyvumą lemiančias } \\
\text { savybes. }\end{array}$ & $n / d$ & 73 \\
\hline \multirow[t]{2}{*}{$\begin{array}{l}\text { Klimato kaitos specialioji programa. Klimato kaitos } \\
\text { valdymo finansinių instrumentų i̇statymas } \\
\text { (Žin., 2009, Nr. 87-3662; 2010, Nr. 145-7427). }\end{array}$} & $\begin{array}{l}\text { Programoje remiamos šios veiklos: fiziniu } \\
\text { ir privačių juridinių asmenu vieno ar dviejų } \\
\text { butu gyvenamuju namų atnaujinimas } \\
\text { pasiekiant pastato energetinio naudingumo } \\
\text { C klasę ir sumažinant energijos suvartojimo } \\
\text { sąnaudas ne mažiau } 20 \% \text {. }\end{array}$ & $n / d$ & 155 \\
\hline & lš viso: & 80 & 558 \\
\hline
\end{tabular}


7 lentelè. Paslaugų sektoriuje igyvendinamos ir planuojamos iggvendinti energijos vartojimo efektyvumo didinimo priemonès

\begin{tabular}{|c|c|c|c|}
\hline Priemonė & $\begin{array}{l}\text { Priemonės aprašymas } \\
\text { (tikslas) }\end{array}$ & $\begin{array}{l}2010 \text { m. } \\
\text { sutaupyta GWh }\end{array}$ & $\begin{array}{l}2016 \mathrm{~m} . \\
\text { planuojama } \\
\text { sutaupyti GWh }\end{array}$ \\
\hline $\begin{array}{l}\text { 2004-2006 m. ES struktūriniai fondai } \\
\text { (ankstyvieji veiksmai) }\end{array}$ & $\begin{array}{l}\text { Mažinti viešosios paskirties pastatuose } \\
\text { suvartojamos energijos sąnaudas. }\end{array}$ & 40 & 40 \\
\hline $\begin{array}{l}\text { Mokyklų ir valstybės institucijų pastatų } \\
\text { energijos taupymo investicijų programa }\end{array}$ & $\begin{array}{l}\text { Mažinti viešosios paskirties pastatuose } \\
\text { suvartojamos energijos sąnaudas. }\end{array}$ & 15 & 15 \\
\hline $\begin{array}{l}\text { 2007-2013 m. periodo ES struktūriniai fondai } \\
\text { (Sanglaudos skatinimo programa). LR Ūkio } \\
\text { ministro } 2008 \text { m. liepos } 14 \text { d. įsakymas } \\
\text { Nr. 4-298 (Žin., 2008, 83-3323). }\end{array}$ & $\begin{array}{l}\text { Mažinti viešosios paskirties pastatuose } \\
\text { suvartojamos energijos sąnaudas. }\end{array}$ & 16 & 100 \\
\hline $\begin{array}{l}\text { Aukštujų mokyklų studentų bendrabučių, } \\
\text { bendrojo lavinimo ir profesinių mokyklų, } \\
\text { mokslo ir studijų institucijų atnaujinimo ir } \\
\text { rekonstrukcijos programos. }\end{array}$ & $\begin{array}{l}\text { Modernizuoti pastatus, kad būtų sudarytos } \\
\text { sąlygos mažinti energijos sąnaudas } \\
\text { pastatuose, gerinti mokymo aplinką } \\
\text { ir ugdymo kokybę. }\end{array}$ & 28 & 28 \\
\hline $\begin{array}{l}\text { Švietimo j̇staigų modernizavimo programa. } \\
\text { LR Vyriausybès } 2008 \text { m. gruodžio } 3 \text { d. } \\
\text { nutarimas Nr. } 1290 \text { (Žin. 2008, 142-5638); } \\
\text { LR Vyriausybès } 2009 \text { m. birželio } 10 \text { d. } \\
\text { nutarimas Nr. } 559 \text { (Žin., 2009, 72-2916). }\end{array}$ & $\begin{array}{l}\text { Modernizuoti švietimo įstaigas, kad būtų } \\
\text { sudarytos sąlygos mažinti energijos } \\
\text { sąnaudas pastatuose, gerinti mokymo } \\
\text { aplinką ir ugdymo kokybę. }\end{array}$ & $n / d$ & 13 \\
\hline $\begin{array}{l}\text { Bibliotekų renovacijos ir modernizavimo } \\
\text { 2003-2013 m. programa. LR Vyriausybès } \\
2002 \text { m. rugsèjo } 17 \text { d. nutarimas } \\
\text { Nr. } 1454 \text { (Žin., 2002, Nr. 92-3943). }\end{array}$ & $\begin{array}{l}\text { Sudaryti bibliotekose tinkamas sąlygas } \\
\text { kaupti, saugoti ir pateikti visuomenei } \\
\text { nacionalinio kultūros ir mokslo paveldo } \\
\text { objektus, užtikrinti fondų prieinamumą. } \\
\text { Vienas iš uždavinių - gerinti bibliotekų } \\
\text { veiklą, renovuoti bibliotekų pastatus. }\end{array}$ & 1 & 4 \\
\hline $\begin{array}{l}\text { Kultūros centrų modernizavimo } \\
2007-2020 \text { m. programa. LR Vyriausybès } \\
2006 \text { m. rugpjūčio } 4 \text { d. nutarimas } \\
\text { Nr. } 785 \text { (Žin., 2006, Nr. 88-3470). }\end{array}$ & $\begin{array}{l}\text { Sudaryti tinkamas savivaldybių kultūros } \\
\text { centrų kultūrinės veiklos sąlygas; } \\
\text { gerinti savivaldybių kultūros centrų } \\
\text { darbuotojų darbo sąlygas; mažinti } \\
\text { savivaldybių kultūros centrų pastatų } \\
\text { eksploatavimo išlaidas. }\end{array}$ & 1 & 6 \\
\hline $\begin{array}{l}\text { Muziejų modernizavimo programa } \\
2007-2015 \text { m. }\end{array}$ & $\begin{array}{l}\text { Modernizuoti pastatus, kad būtų sudarytos } \\
\text { sąlygos mažinti energijos sąnaudas } \\
\text { pastatuose, gerinti mokymo aplinką ir } \\
\text { ugdymo kokybę. }\end{array}$ & $\mathrm{n} / \mathrm{d}$ & 1 \\
\hline $\begin{array}{l}\text { lkalinimo jistaigų renovavimo programa } \\
\text { 2004-2009 m. }\end{array}$ & $\begin{array}{l}\text { Modernizuoti pastatus, kad būtų sudarytos } \\
\text { sąlygos mažinti energijos sąnaudas } \\
\text { pastatuose, gerinti mokymo aplinką ir } \\
\text { ugdymo kokybę. }\end{array}$ & $\mathrm{n} / \mathrm{d}$ & 5 \\
\hline $\begin{array}{l}\text { Specialioji programa „Energijos taupymo } \\
\text { projektų igyvendinimas“ 2004-2008 m. }\end{array}$ & $\begin{array}{l}\text { Modernizuoti mokyklų, lopšelių-darželių } \\
\text { ir ligoninių pastatus, kad būtų sudarytos } \\
\text { sąlygos mažinti energijos sąnaudas } \\
\text { pastatuose, gerinti mokymo aplinką ir } \\
\text { ugdymo kokybę. }\end{array}$ & 6 & 6 \\
\hline $\begin{array}{l}\text { Savivaldybių švietimo ir kultūros, sveikatos } \\
\text { ir socialinės paskirties statinių rekonstravimo } \\
\text { programa 2003-2008 m. }\end{array}$ & $\begin{array}{l}\text { Modernizuoti pastatus, kad būtų sudarytos } \\
\text { sąlygos mažinti energijos sąnaudas } \\
\text { pastatuose, gerinti mokymo aplinką ir } \\
\text { ugdymo kokybę. }\end{array}$ & $n / d$ & 5 \\
\hline $\begin{array}{l}\text { Ignalinos atominės regiono savivaldybių } \\
\text { viešosios paskirties pastatų energijos } \\
\text { efektyvumo didinimas }\end{array}$ & $\begin{array}{l}\text { Modernizuoti pastatus, kad būtų sudarytos } \\
\text { sąlygos mažinti energijos sąnaudas } \\
\text { pastatuose, gerinti mokymo aplinką ir } \\
\text { ugdymo kokybę. }\end{array}$ & 3 & 19 \\
\hline $\begin{array}{l}\text { Energijos efektyvumo reikalavimai viešujų pirkimų } \\
\text { metu. Prekių, kurioms viešuju pirkimų } \\
\text { metu taikomi energijos vartojimo } \\
\text { efektyvumo reikalavimai ir šių } \\
\text { prekių energijos vartojimo } \\
\text { efektyvumo reikalavimų sąrašas, } \\
\text { patvirtintas } 2008 \text { m. spalio } 8 \mathrm{~d} \text {. } \\
\text { LR Vyriausybės nutarimu Nr. } 1023 \\
\text { (Žin., 2008, Nr. 121-4600). }\end{array}$ & $\begin{array}{l}\text { Senų prietaisų keitimas naujais, } \\
\text { energetiškai efektyvesniais, tiesiogiai } \\
\text { mažina energijos sunaudojimą. }\end{array}$ & $n / d$ & $n / d$ \\
\hline
\end{tabular}


7 lentelè. Tęsinys

\begin{tabular}{|c|c|c|c|}
\hline Priemonė & $\begin{array}{c}\text { Priemonės aprašymas } \\
\text { (tikslas) }\end{array}$ & $\begin{array}{c}2010 \mathrm{~m} . \\
\text { sutaupyta GWh }\end{array}$ & $\begin{array}{c}2016 \mathrm{~m} . \\
\text { planuojama } \\
\text { sutaupyti GWh }\end{array}$ \\
\hline $\begin{array}{l}\text { Klimato kaitos specialioji programa. } \\
\text { Klimato kaitos valdymo finansiniu } \\
\text { instrumentu istatymas } \\
\text { (Žin., 2009, Nr. 87-3662; 2010, } \\
\text { Nr. 145-7427). }\end{array}$ & $\begin{array}{l}\text { Pagal programą remiamos šios veiklos: } \\
\text { visuomeninės paskirties pastatų atnaujini- } \\
\text { mas (modernizavimas) mažinant energijos } \\
\text { suvartojimo sąnaudas; visuomeninės } \\
\text { paskirties pasyvaus arba mažai energijos } \\
\text { vartojančio pastato statybos arba visuo- } \\
\text { meninės paskirties pastatu atnaujinimas } \\
\text { (modernizavimas) siekiant mažo arba } \\
\text { pasyvaus energijos vartojimo; elektros } \\
\text { energijos vartojimo efektyvumą didinančių } \\
\text { priemonių diegimas viešosiose erdvėse. }\end{array}$ & $n / d$ & 170 \\
\hline \multirow[t]{2}{*}{$\begin{array}{l}\text { Planuojama įgyvendinti } \\
\text { priemone - savanoriški susitarimai } \\
\text { su įmonėmis. }\end{array}$} & & $n / d$ & 370 \\
\hline & Iš viso: & 110 & 387 \\
\hline
\end{tabular}

Kaip matyti iš 7 lentelèje pateiktos informacijos, didžiausi galutinès energijos kiekiai paslaugų sektoriuje buvo sutaupyti 2004-2006 m. struktūrinių fondų lèšomis igyvendinant visuomeninių pastatų renovaciją, o laukiamas didžiausias energijos taupymo potencialo realizavimas 2016 m. taip pat yra susijęs su ES struktūrinių fondų 2007-2013 m. panaudojimu renovuojant visuomeninius pastatus. Vykdytos valstybės finansuojamos Aukštųjų mokyklų studentų bendrabučių, bendrojo lavinimo ir profesinių mokyklų, mokslo ir studijų institucijų atnaujinimo ir rekonstrukcijos programos leido $2010 \mathrm{~m}$. sutaupyti apie 30 GWh galutinès energijos. Pagrindinès priemonės, kurių rezultatai yra išreikšti sutaupytos energijos kiekiais, yra susijusios su subsidijomis. Tokių priemonių, kaip savanoriški susitarimai, energijos efektyvumo reikalavimai viešųjų pirkimų metu arba žalieji pirkimai, energijos taupymo rezultatai nèra nustatyti, nes savanoriški susitarimai yra tik planuojamos priemonès ir jų igyvendinimo poveikis bus ivertintas tik $2016 \mathrm{~m}$.

Be igyvendintų ir igyvendinamų energijos vartojimo efektyvumo didinimo priemonių pastatuose (namų ūkių ir paslaugų sektoriuose), bendrajj nacionalinį energijos taupymo rodikli galima pasiekti igyvendinant ir kitas sektorines bei horizontaliąsias energijos vartojimo efektyvumo didinimo priemones. 8 lenteleje pateikiamas horizontaliųų energijos vartojimo efektyvumo didinimo priemonių aprašymas.

$2010 \mathrm{~m}$. dèl horizontaliųjų priemonių igyvendinimo buvo sutaupyta $590 \mathrm{GWh}$ arba $76 \% 2010 \mathrm{~m}$. nustatyto energijos taupymo rodiklio. $2015 \mathrm{~m}$. nustatytas dar ambicingesnis tikslas - sutaupyti $990 \mathrm{GWh}$ energijos. Šis taupymas yra susijęs su Statybos techninio reglamento STR 2.05.01:2005 "Pastatų atitvarų šiluminè technika“ igyvendinimu. Nacionalinès energetikos (energetinès nepriklausomybès) strategijoje, patvirtintoje LR Seimo 2012 m., numatyta kasmet sutaupyti 2-3 TWh šilumos.
Tokių priemonių, kaip gaminių ženklinimas, ekologinis projektavimas bei mokesčio už aplinkos teršimą lengvata, poveikis galutinès energijos taupymui nèra įvertintas.

Atlikta analizè parodè, kad Lietuvoje energijos efektyvumo didinimo politika pastatų sektoriuje yra orientuota $\mathfrak{i}$ subsidijas bei kontrolès ir reguliavimo instrumentus. Lankstiesiems bei informaciniams instrumentams ir savanoriškiems įsipareigojimams, kurie yra ekonomiškai efektyviausios energijos taupymo bei pigiausios ŠESD emisiju mažinimo priemonès, iki šiol Lietuvoje buvo skiriamas nepakankamas dèmesys.

Remdamiesi atlikta analize galime teigti, kad Lietuvos energijos efektyvumo didinimo politika yra orientuota $i$ brangias, tačiau didžiausią energijos taupymo potencialą garantuojančias priemones, tačiau nepakankamai panaudojamos pigios, nors ir ne aukštu energijos taupymo bei ŠESD emisijų mažinimo potencialu pasižyminčios, priemonès: savanoriški susitarimai, energijos efektyvumo reikalavimai viešųjų pirkimų metu arba žalieji pirkimai. Informacinès priemonès taip pat nèra pakankamai išnaudojamos Lietuvoje, todèl šalies energijos efektyvumo didinimo politiką reikètų nukreipti į energijos taupymo elgsenos formavimą namų ūkiuose bei biuruose. Šiuo metu pasaulyje populiari ne tik darnaus gyventoju energijos vartojimo bei žaliụjų biurų koncepcija. Žalieji biurai yra modernūs pastatai, kuriuose yra įdiegtos moderniausios technologijos, inovacijos, didelis dėmesys skiriamas mažam energijos vartojimui. Svarbų vaidmeni vaidina ir „žalioji elgsena biure“: pačių darbuotojų elgsena naudojant mažiau energijos ir taupant visais įmanomais būdais. Analogiškai gyventojai turètų būti skatinami ne tik diegti inovacijas ir taupyti energiją modernizuodami būstus bei pirkdami efektyvesnius prietaisus, bet ir keisdami savo elgseną bei taupydami energiją. Šioms priemonèms Lietuvoje yra skiriamas nepakankamas dèmesys. 
8 Ientelè. Horizontaliosios energijos vartojimo efektyvumo didinimo priemonès

\begin{tabular}{|c|c|c|c|}
\hline Priemonė & Priemonės aprašymas & $\begin{array}{l}2010 \mathrm{~m} . \\
\text { sutaupyta } \\
\text { GWh }\end{array}$ & $\begin{array}{c}2016 \mathrm{~m} . \\
\text { planuojama } \\
\text { sutaupyti GWh }\end{array}$ \\
\hline $\begin{array}{l}\text { Nacionalinė energetinès } \\
\text { nepriklausomybès } \\
\text { strategija }\end{array}$ & $\begin{array}{l}\text { Nacionalinės energetikos (energetinės nepriklausomybės) strategijoje } \\
\text { numatomų energetikos politikos krypčių ir veiksmų tikslas - Lietuvos } \\
\text { energetinės nepriklausomybės iki } 2020 \text { m. užtikrinimas. } \\
\text { Energetinio efektyvumo didinimo srityje iki } 2020 \text { m. bus siekiama kasmet } \\
\text { po 1,5 \% didinti energijos vartojimo efektyvumą ir taip stiprinti ener- } \\
\text { getinę nepriklausomybę, konkurencingumą ir darnią plètrą. Numatyta } \\
\text { padidinti šilumos gamybos, perdavimo ir vartojimo efektyvumą, tuo pat } \\
\text { metu keičiant šilumos gamybai naudojamas gamtines dujas biomase. } \\
\text { Valstybė rems iniciatyvas, didinančias energijos vartojimo efektyvumą, } \\
\text { skatinančias atlieku panaudojimą energijai gaminti ir didinančias bioma- } \\
\text { sės naudojimą šilumos gamybai. Per ši dešimtmeti Lietuva sumažins šilu- } \\
\text { mos suvartojimą gyvenamuosiuose namuose ir viešuosiuose pastatuose } \\
\text { 30-40\%. Palyginti su } 2009 \text { m., tai kasmet leis sutaupyti } 2-3 \text { TWh šilumos. }\end{array}$ & $\mathrm{n} / \mathrm{d}$ & $\mathrm{n} / \mathrm{d}$ \\
\hline $\begin{array}{l}\text { Nacionalinė energijos } \\
\text { vartojimo efektyvumo } \\
\text { didinimo programa } \\
2011-2015 \mathrm{~m} .\end{array}$ & 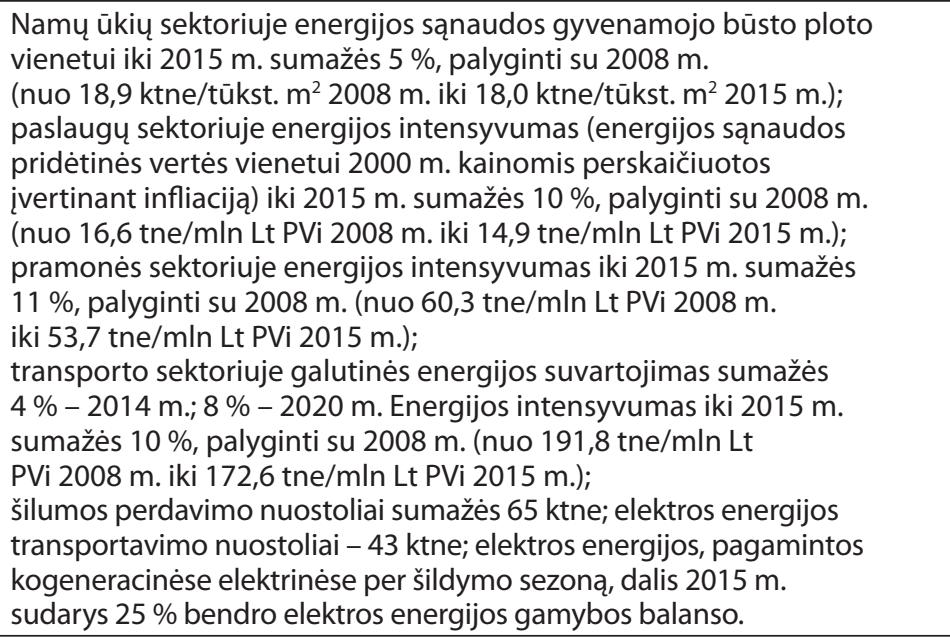 & $\mathrm{n} / \mathrm{d}$ & $\mathrm{n} / \mathrm{d}$ \\
\hline $\begin{array}{l}\text { Statybos techninis regla- } \\
\text { mentas STR 2.05.01:2005 } \\
\text { „Pastatų atitvarų } \\
\text { šiluminė technika" }\end{array}$ & Tikslas - mažinti pastatuose suvartojamos energijos sąnaudas. & 590 & 1240 \\
\hline $\begin{array}{l}\text { Statybos techninis regla- } \\
\text { mentas STR 2.09.02:2005 } \\
\text { „Šildymas, vèdinimas, } \\
\text { oro kondicionavimas" }\end{array}$ & Mažinti pastatuose suvartojamos energijos sąnaudas. & $\mathrm{n} / \mathrm{d}$ & $\mathrm{n} / \mathrm{d}$ \\
\hline $\begin{array}{l}\text { Statybos techninis regla- } \\
\text { mentas STR 2.01.09:2005 } \\
\text { „Pastatų energinis naudin- } \\
\text { gumas. Energinio naudin- } \\
\text { gumo sertifikavimas" }\end{array}$ & $\begin{array}{l}\text { Užtikrinti, kad statybos objektai ir jų įranga būtų suprojektuota ir įrengta } \\
\text { taip, kad, atsižvelgiant i vietovès klimato ir gyventojų komforto sąlygas, } \\
\text { energijos suvartojimas būtų mažesnis; siekiama, kad nauji pastatai atitiktų } \\
\text { minimalius energinio naudingumo reikalavimus, kad pastatų energinį } \\
\text { naudingumą didinantys veiksniai būtų išnaudojami optimaliai. }\end{array}$ & $\mathrm{n} / \mathrm{d}$ & $\mathrm{n} / \mathrm{d}$ \\
\hline $\begin{array}{l}\text { Šildymo sistemų } \\
\text { su katilais efektyvumo } \\
\text { tikrinimas }\end{array}$ & $\begin{array}{l}\text { Nustatyti pastatuose įrengtų ne mažesnès kaip } 20 \text { kW vardinės atiduo- } \\
\text { damosios galios ir naudojančių neatsinaujinantį kietajį arba skystaji kurą } \\
\text { šildymo katilų nuolatinius efektyvumo tikrinimus bei šildymo sistemų } \\
\text { su senesniais kaip } 15 \text { metų katilais vienkartinį efektyvumo tikrinimą } \\
\text { siekiant, kad katilų bei šildymo sistemų efektyvumas atitiktų } \\
\text { ekonomiškai pagrįstus reikalavimus. }\end{array}$ & $\mathrm{n} / \mathrm{d}$ & $\mathrm{n} / \mathrm{d}$ \\
\hline $\begin{array}{l}\text { Oro kondicionavimo } \\
\text { sistemų efektyvumo } \\
\text { tikrinimas }\end{array}$ & $\begin{array}{l}\text { Tikslas - nustatyti pastatuose įrengtų didesnès kaip } 12 \mathrm{~kW} \text { vardinès } \\
\text { atiduodamosios galios oro kondicionavimo sistemų nuolatinius efek- } \\
\text { tyvumo tikrinimus siekiant, kad kondicionavimo sistemos efektyvumas } \\
\text { atitiktu ekonomiškai pagristus reikalavimus, o vardinè atiduodamoji } \\
\text { galia - pastato vèsinimo poreikius. }\end{array}$ & $\mathrm{n} / \mathrm{d}$ & $\mathrm{n} / \mathrm{d}$ \\
\hline $\begin{array}{l}\text { Mokesčio už aplinkos } \\
\text { teršimą lengvata }\end{array}$ & $\begin{array}{l}\text { Lengvatos paskirtis - ekonominėmis priemonėmis skatinti teršèjus ma- } \\
\text { žinti aplinkos teršimą, vykdyti atliekų prevenciją ir tvarkymą, neviršyti } \\
\text { nustatytų teršalų išmetimo į aplinką normatyvų, taip pat iš mokesčio } \\
\text { kaupti lèšas aplinkosaugos priemonėms igyvendinti. }\end{array}$ & $\mathrm{n} / \mathrm{d}$ & $\mathrm{n} / \mathrm{d}$ \\
\hline $\begin{array}{l}\text { Su energijos vartojimu } \\
\text { susijusių gaminių } \\
\text { ženklinimas }\end{array}$ & $\begin{array}{l}\text { Informuoti galutinius vartotojus apie gaminių suvartojamą energiją, } \\
\text { suteikti vartotojams galimybę pasirinkti energijos požiūriu } \\
\text { efektyviausius prietaisus. }\end{array}$ & $\mathrm{n} / \mathrm{d}$ & $\mathrm{n} / \mathrm{d}$ \\
\hline
\end{tabular}


8 lentelè. Tęsinys

\begin{tabular}{|c|c|c|c|}
\hline Priemonè & Priemonès aprašymas & $\begin{array}{c}2010 \mathrm{~m} . \\
\text { sutaupyta } \\
\text { GWh }\end{array}$ & $\begin{array}{c}2016 \mathrm{~m} . \\
\text { planuojama } \\
\text { sutaupyti GWh }\end{array}$ \\
\hline \multirow[t]{2}{*}{$\begin{array}{l}\text { Ekologinis projektavimas } \\
\text { (ekodizainas) }\end{array}$} & $\begin{array}{l}\text { Ekologiniu projektavimu siekiama pagerinti gaminių ekologiškumą } \\
\text { per visą ju gyvavimo ciklą (žaliavų parinkimas ir naudojimas; gamyba; } \\
\text { pakavimas, transportavimas bei platinimas; irengimas ir eksploatacija; } \\
\text { naudojimas ir gyvavimo pabaiga), ekologiškumą sistemingai } \\
\text { itraukiant pačiu ankstyviausiu gaminio projektavimo etapu. }\end{array}$ & $n / d$ & $n / d$ \\
\hline & Iš viso: & 590 & 1240 \\
\hline
\end{tabular}

Socialinė reklama leistų ne tik pagerinti gyventojų žinias apie energijos taupymo galimybes namuose bei biuruose, bet ir primintų, kad tai būtina daryti nuolatos ir formuotų ekologinę gyventojų elgseną.

\section{IŠVADOS}

1. Energijos taupymas yra pigiausia ŠESD emisijų mažinimo priemonè, o pastatų sektoriuje glūdi didžiausias energijos taupymo bei ŠESD emisijų mažinimo potencialas, kurị galima realizuoti mažiausiais kaštais. Skirtingos priemonès, nukreiptos ị energijos taupymą pastatuose, pasižymi skirtingu efektyvumu ir rezultatyvumu, kuriuos apibūdina energijos taupymo bei ŠESD mažinimo kaštai bei potencialas.

2. Apibendrinus užsienyje atliktų tyrimų rezultatus galima teigti, kad pigiausi energijos taupymo ir ŠESD emisijų mažinimo instrumentai pastatų srityje yra prekyba baltaisiais sertifikatais ir savanoriški susitarimai. Informacinès priemonės taip pat leidžia pigiai sumažinti ŠESD emisijas - 8 JAV dol./tCO, o Lankstieji Kioto protokolo mechanizmai užtikrina ŠESD emisijų mažẻjimą pastatuose nuo 10 iki 57 JAV dol./tCO (remiantis Baltijos šalių duomenimis).

3. Brangiausios energijos taupymo ir ŠESD emisijų mažinimo priemonès pastatuose yra prietaisų standartai, kuriuos igyvendinus ŠESD mažinimo kaštai siekia 194 JAV dol./tCO bei statybos normos, kurias taikant ŠESD mažinimo kaštai - $189 \mathrm{JAV}$ dol./tCO . Brangios yra privalomos ženklinimo ir sertifikavimo sistemos, leidžiančios sumažinti ŠESD emisijas kaštais, svyruojančiais nuo 209,3 JAV dol./tCO 2 (Danija) iki $255 \mathrm{JAV}$ dol./tCO .

4. Poreikių valdymo programos energijos tiekimo įmonèse taip pat gali būti priskiriamos prie brangiausių ŠESD emisijų mažinimo instrumentų. ŠESD emisijų mažinimo kaštai siekia 209,3 JAV dol./tCO 2 Danijoje, o ES vidurkis - $255 \mathrm{JAV}$ dol./tCO $\mathrm{CO}_{2}$ Taigi pigiausios yra ekonominès arba rinkos priemonès bei savanoriški įsipareigojimai, o brangiausios - kontrolès ir reguliavimo priemonès.

5. Didžiausias ŠESD emisijų mažinimo potencialą gali užtikrinti viešieji pirkimai ir statybų normos. Taip pat didelis ŠESD emisijų mažinimo potencialas glūdi ir subsidijose bei dotacijose. Iprasta, kad pigios priemonès, tokios kaip savanoriški susitarimai arba švietėjiškos priemonès, pasi- žymi mažu energijos taupymo ir ŠESD emisijų mažinimo potencialu, išskyrus viešuosius prikimus, kurie gali garantuoti 20-44 $\mathrm{MtCO}_{2} /$ metus potencialą ES su mažesniais nei $21 \mathrm{JAV}$ dol./tCO $\mathrm{S}_{2} \mathrm{ESD}$ mažinimo kaštais.

6. Lietuvos energijos efektyvumo didinimo politika yra orientuota i brangias, tačiau didžiausią energijos taupymo potencialą garantuojančias priemones, tačiau nepakankamai panaudojamos, pigios, nors ir palyginti mažu energijos taupymo bei ŠESD emisijų mažinimo potencialu pasižyminčios priemonès: savanoriški susitarimai, energijos efektyvumo reikalavimai viešuju pirkimų metu arba žalieji pirkimai.

7. Informacinès priemonès Lietuvoje irgi nèra pakankamai išnaudojamos, todèl šalies energijos efektyvumo didinimo politiką visų pirma reikètų nukreipti i energijos taupymo elgsenos formavimą namu ūkiuose bei biuruose. Lietuvos gyventojai socialinès reklamos pagalba turètų būti skatinami ne tik diegti inovacijas ir taupyti energiją modernizuodami būstus ar pirkdami efektyvesnius prietaisus, bet ir keisdami savo elgseną bei taupydami energiją tiek namuose, tiek darbo vietoje. Socialinè reklama leistų ne tik pagerinti gyventojų žinias apie energijos taupymo galimybes namuose bei biuruose, bet ir primintų, kad tai būtina daryti nuolatos, formuotu ekologinę gyventojų elgseną Lietuvoje.

Tyrimą finansuoja Lietuvos mokslo taryba (Sutartis MIP004/2012).

Gauta 20120615 Priimta 20120805

\section{Literatūra}

1. Jaraminiene E., Bieksa D., Valuntiene I. Estimating potential and costs of reducing $\mathrm{CO}_{2}$ emissions in Lithuanian Buildings. Environmental Research, Engineering and Management. 2012. Vol. 59. No. 1. P. 23-30.

2. IPCC. Fourth Assessment Report of the Intergovernmental Panel on Climate Change. Cambridge, NY: Cambridge University Press, 2007.

3. Hogg D. The limitations of economic instruments as stimuli for technical change, technological change and innovation. In: Andersen M. S., Sprenger R. U. (eds.). 
Market-based Instruments for Environmental Management: Politics and Institutions. Edward Elgar, Cheltenham, 2000. P. 87-92.

4. Jakob M. Marginal costs and co-benefits of energy efficiency investments: The case of the Swiss residential sector. Energy Policy. 2006. Vol. 34. No. 2. P. 172-187.

5. Harmelink M., Nilsson L., Harmsen R. Theory-based policy evaluation of 20 energy efficiency instruments. Energy Efficiency. 2008. Vol. 1. P. 131-148.

6. Kavgic M., Mavrogianni A., Mumovic D., Summerfield A., Stevanovic Z., Djurovic-Petrovic M. A review of bottom-up building stock models for energy consumption in the residential sector. Building and Environment. 2010. Vol. 45. No. 7. P. 1683-1697.

7. Kuriyan R., Kammen D. How to use technology to spur development. Issues in Science and Technology. 2008. P. 70-74.

8. Kammen D. Opportunities for GHG reduction. House of Representatives Committee on Oversight and Government Reform. 2007. No. 8. P. 1-13.

9. Kammen D. M., Pacca S. Assessing the costs of electricity. Annual Review of Energy and Environment. 2004. No. 29. P. 301-344.

10. Nemet G. F., Kammen D. M. U. S. energy research and development: Declining investment, increasing need, and the feasibility of expansion. Energy Policy. 2007. Vol. 35. No. 1. P. 746-755.

11. Porchia R., Bigano A. Development of a set of full cost estimates of the use of different energy sources and its comparative assessment in EU countries. CASES WP6 report. Total Energy Costs in EU Countries. FEEM, Milano, 2008.

12. Urge-Vorsatz D., Novikova A. Potentials and costs of carbon dioxide mitigation in the world's buildings. Energy Policy. 2008. Vol. 36. No. 2. P. 642-661.

13. Milutiene E. House embodied energy and zero energy building concept. Aplinkos tyrimai, inžinerija ir vadyba. 2010. Nr. 4(54). P. 62-71.

14. Milutienė E., Maršalka A., Staniškis J., Augulienė V. Investigation of energy saving possibilities in buildings. Aplinkos tyrimai, inžinerija ir vadyba. 2010. Nr. 1(51). P. 40-46.

15. UNEP. Assessment of Policy Instruments for Reducing Greenhouse Gas Emissions from Buildings. Budapest: Central European University, 2007.

16. Vanvuuren D., Hoogwijk M., Barker T., Riahi K., Boeters S., Chateau J., Scrieciu S., van Vliet J., Masui T., Blok K., Blomen E., Kram T. Comparison of top-down and bottom-up estimates of sectoral and regional greenhouse gas emission reduction potentials. Energy Policy. 2010. Vol. 37. No. 12. P. 5125-5139.

17. Antrasis energijos efektyvumo didinimo veiksmu planas. Lietuvos Respublikos energetikos ministerija, 2011. Vilnius.
Dalia Štreimikienè, Asta Mikalauskienè

\section{MEASURES TO INCREASE ENERGY EFFICIENCY AND THEIR COST-EFFECTIVENESS}

\section{Summary}

This article examines energy efficiency improvement policy, the main attention being paid to energy efficiency improvements in buildings of households and services sectors as well. The paper analyses the main EU energy policy documents dealing with energy efficiency policy and their targets. The Lithuanian energy policy documents targeting energy efficiency improvement are analyzed and progress in achieving the energy efficiency targets set for Lithuania is assessed. Based on the results and findings of energy saving and the GHG emission reduction potential and costs analyses performed in $\mathrm{EU}$, the costs and $\mathrm{GHG}$ emission reduction potential in buildings are generalized. The recommendations for energy efficiency policy improvement in Lithuania are developed based on the Lithuanian energy policy analysis and the findings of energy saving and the GHG emission reduction potential and costs analyses.

Key words: energy efficiency, energy policy, measures, buildings

Даля Штреймикене, Аста Микалаускене

\section{МЕРЫ ПО ПОВЫШЕНИЮ ЭНЕРГОЭФФЕКТИВНОСТИ И ИХ ЭФФЕКТИВНОСТЬ}

\section{Резюме}

В данной статье анализируется политика энергоэффективности, акцент делается на меры по повышению энергоэффективности в зданиях, в домашнем хозяйстве и в сфере услуг. В статье анализируются приоритетные документы ЕС, связанные с политикой энергоэффективности и оценен прогресс Литвы в реализации энергетических целей повышения эффективности. На основе экономии и сметы расходов энергии и выбросов парниковых газов, сделанных странами ЕС, выработаны рекомендации для реализации политики энергоэффективности в Литве, уделив особое внимание секторам, которые предлагают наименьшие расходы по сокращению выбросов парниковых газов, высокую энергетическую эффективность энергии и высокий потенциал по сокращению выбросов парниковых газов.

Ключевые слова: энергосбережение, политика, инструменты, здания 